\title{
Assessment of groundwater recharge potential zone using GIS approach in Purworejo regency, Central Java province, Indonesia
}

\author{
Daniel Eko Aryanto ${ }^{1, *}$, Gagoek Hardiman ${ }^{2}$ \\ ${ }^{1}$ Master Program of Environmental Science, School of Postgraduate Studies, Diponegoro Univers ity, Semarang-Indonesia \\ ${ }^{2}$ Faculty of Engineering, Diponegoro University, Semarang-Indonesia
}

\begin{abstract}
Floods and droughts in Purworejo regency are an indication of problems in groundwater management. The current development progress has led to land conversion which has an impact on the problem of water infiltration in Purworejo regency. This study aims to determine the distribution of groundwater recharge potential zones by using geographic information system as the basis for ground water management. The groundwater recharge potential zone is obtained by overlaying all the thematic maps that affect the groundwater infiltration. Each thematic map is weighted according to its effect on groundwater infiltration such as land-use - $25 \%$, rainfall - 20\%, litology $-20 \%$, soil - $15 \%$, slope - 10\%, lineament $-5 \%$, and river density $-5 \%$ to find groundwater recharge potential zones. The groundwater recharge potential zones thus obtained were divided into five categories, viz., very high, high, medium, low and very low zones. The results of this study may be useful for better groundwater planning and management.
\end{abstract}

\section{Introduction}

Ground water is the amount of water beneath the earth's surface that can be collected with wells, tunnels or drainage systems or by pumping. It can also be called a stream that naturally flows into the soil surface through jets or seepage [1]. The availability of ground water in a region is very important for the survival of the region.

Purworejo as one of the regencies in Central Java Province, based on the results of the research have alert status related to water balance and critical water resources per Regency in Central Java [1]. While another study concluded that by 2025 the number of districts with water deficits increased by 78.4 percent with deficits ranging from one to twelve months, or deficits throughout the year. This means that water availability in Purworejo regency needs to serious attention to its conservation.

The rapid development in Purworejo regency has caused land conversion which resulted in the decreasing of area for groundwater infiltration. The reduced water catchment area causes groundwater filling to be disrupted and result in a decrease in groundwater availability. In general, water infiltration process occurs through the filtration process (movement of water from the top into the soil surface) and percolation (ground water movement down from the unsaturated zone into the saturation zone) that occur sequentially. Infiltration rate will be equal to rain intensity if infiltration rate is still less than infiltration power. Percolation will not occur if porosity in the zone is not saturated yet optimally contain water [3].

Disaster occurring in Purworejo regency, the floods that occur almost every year that cause fatalities and property [4], as well as droughts that cause the residents difficulty to get clean water [5] is an indication of problems related to groundwater infiltration. Rainwater that is not maximally infiltrated into the ground causes such a disaster.

The absence of a comprehensive groundwater recharge potential zone map in Purworejo Regency has resulted in the development program not considering the catchment area as an area that should be protected and conserved as part of groundwater conservation. Groundwater recharge area is the area where the rain water infiltrated into the soil which then becomes ground water.

To determine the potential groundwater recharge area is to use mapping and processing through Geographic Information System. Geographic Information System (GIS) is a computer-based system or technology constructed for the purpose of collecting, storing, processing and analyzing, and presenting data and information of an object or phenomenon related to its location or existence Earth surface. Basically GIS can be broken down into several interrelated sub-systems that include data input, data management, data processing or analysis, reporting (output) and data results [6].

Mapping of potential groundwater recharge potential zones using Geographic Information System

Corresponding author: dea.nuha@gmail.com 
has been done by many researchers, such as Manap et al. [7], Madani and Niyazi [8], Elbeih [9], Nagarajan [10], Oikonomidis, et al. [11], Senanayake, et al. [12]. Some steps taken to obtain the groundwater recharge potential map are: (1) identification of thematic map that influences groundwater infiltration. (2) weighting and scoring on each thematic map. (3) a thematic map application with a GIS program for spatial mapping.

\section{Study Area}

Purworejo is one of regency in Central Java province, located between $109^{\circ} 47^{\prime} 28^{\prime \prime}$ to $110^{\circ} 8^{\prime} 20^{\prime \prime}$ East Longitude and between $7^{\circ} 32$ to $7^{\circ} 54^{\prime \prime}$ South Latitude. North of Purworejo borders Magelang and Wonosobo, South by the Indonesian Ocean. The west of Purworejo borders Kebumen Regency and the east borders of Yogyakarta Province precisely Kulonprogo Regency [13].
Topographical of Purworejo is wet tropical regions with temperatures between $19^{\circ} \mathrm{C}-28^{\circ} \mathrm{C}$ while humidity between 70 percent until 90 percent.

Purworejo regency has an area of Groundwater Basin and Non Basin of Ground Water. The Groundwater Basin for Purworejo Regency is in accordance with Presidential Decree Number 26 of 2011 on the Establishment of Groundwater Basin [14], including in Kebumen-Purworejo Groundwater Basin with Longitude Coordinate: $109^{\circ} 27^{\prime} 18.50^{\prime \prime}-110^{\circ} 03^{\prime} 36.50^{\prime \prime}$ and latitude coordinates : $-07^{\circ} 34^{\prime} 14.61^{\prime \prime}$ - $-07^{\circ} 53^{\prime} 59.96 "$ ".

\section{Methodology}

Groundwater recharge refers to the entry of water from the saturated zone into unsaturated zone. Below the water table surface, together with the associated flow away from the water table within the saturated zone.
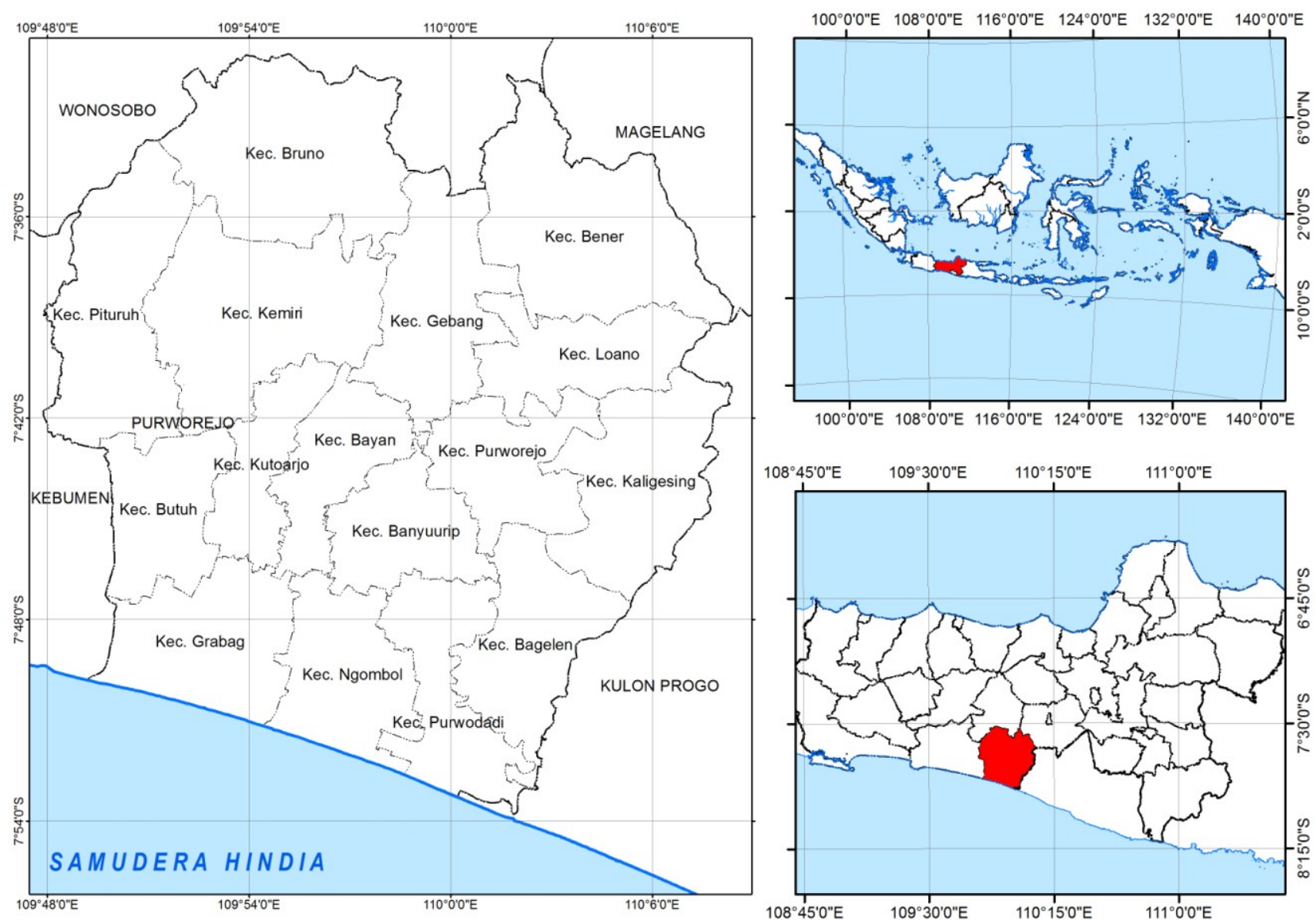

Fig. 1. Location map of the study area, Purworejo regency, Central Java province, Indonesia

Purworejo Regency is divided into 16 sub districts and 494 villages. Region of Purworejo in 2015 has vast 103,481 ha or about 3.18 percent of Jawa Tengah. Land area of 103,481 ha in Purworejo consists of 87,105 ha (84.18 percent) of agricultural land and 16,375 ha (15.82 percent) is non agricultural land. Agricultural land that is used as a wetland 30,225 ha $(34,70$ percent $)$ and non wetland 56,880 ha (65.30 percent). 

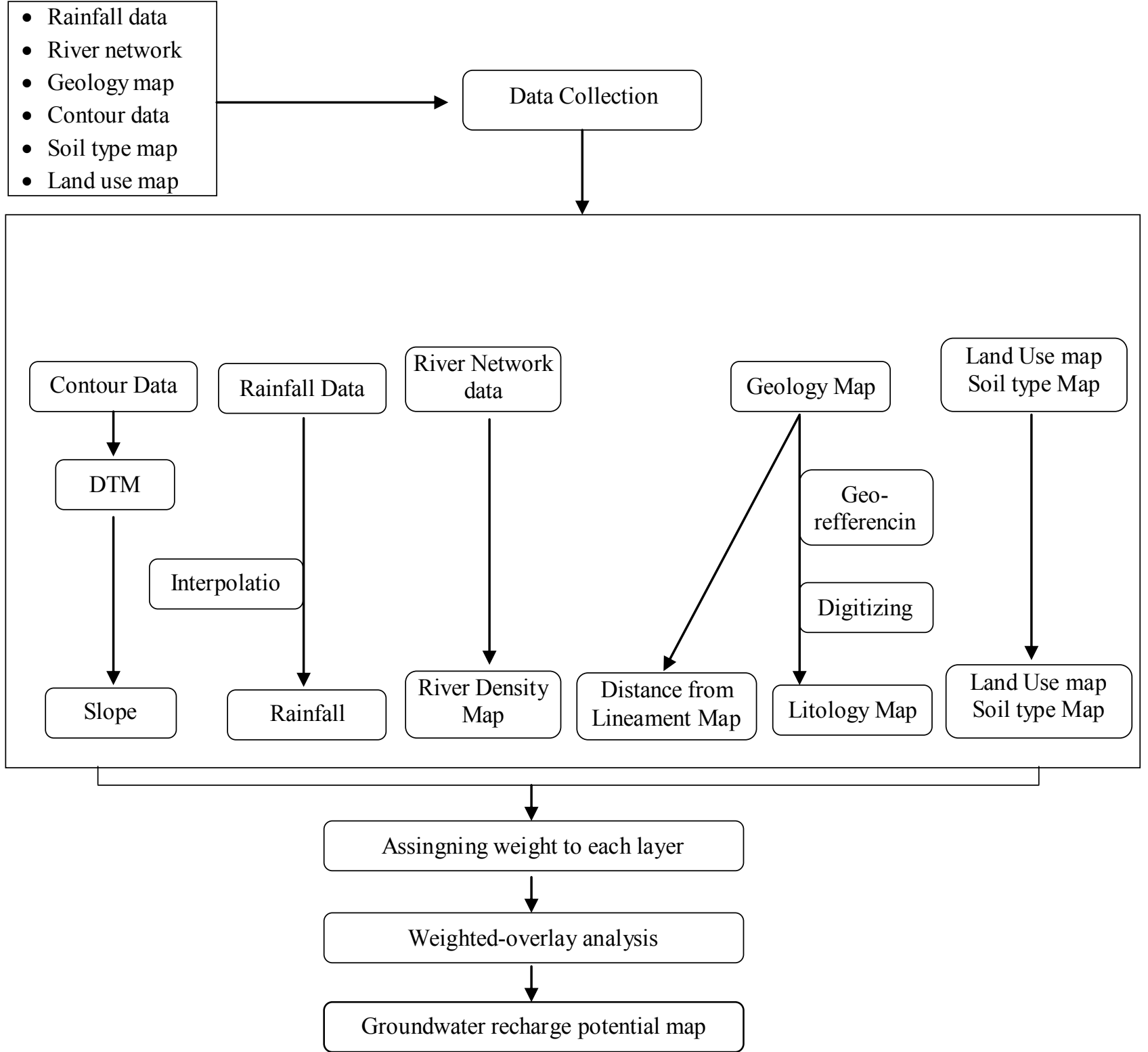

Fig. 2. Flow chart of the metodology employed in the study to delineate groundwater recharge potential of Purworejo regency.

Recharge occurs when water flows past the groundwater level and infiltrates into saturated zone. It is an extremely important water component of the circulation cycle in nature [15].

With the development of remote-sensing technology and its spatially accurate performance in georeference processes, the factors influential to groundwater prospect zonation can be more easily identified on a broad scale [16]. GIS approach were employed in this study to delineate the groundwater recharge potential of Purworejo regency based on time and cost effectiveness [10]. Identification of suitable zones for groundwater recharge was conducted through a knowledge-based factor analysis, using rainfall, land, use, lithology, soil type, slope, river density, and distance from lineament layers.
The methodology followed in this study to delineate suitable sites for groundwater recharging has been illustrated in Fig. 2.

\subsection{Weightage}

Weighting for identification of groundwater recharge [potential zones has been done by many researchers using geographic information systems. This research uses a subjective approach, where the final result depends on the signification level of the thematic map and the weighting factor used in this study. The integration of the layer factor that influences the groundwater recharge using overlay method in a GIS platform in this study is presented in Table 1. 
Table 1. Rank and weight for factors used for groundwater potentiality mapping (modified after ; Wibowo, [3]; Madani \& Niyazi, [8]; Elbeih, [9]; Nagarajan \& Singh, [10]; Oikonomidis, Dimogianni, Kazakis, \& Voudouris, [11]; Senanayake, Dissanayake, Mayadunna, \& Weerasekera, [12];; Yeh, Cheng, Lin, \& Lee, [15]; Ahmed, [17]; Magesh, Chandrasekar, \& Soundranayagam, [18]; Sigit, [19]; Adibah, [20]).

\begin{tabular}{|c|c|c|c|c|}
\hline Parameters & Class & & Rank & $\begin{array}{c}\text { Weight } \\
(\%)\end{array}$ \\
\hline \multirow{5}{*}{ Land use } & Very high & Forest & 5 & \multirow{5}{*}{25} \\
\hline & High & Garden & 4 & \\
\hline & Moderate & Shrubs & 3 & \\
\hline & Low & Empty land. & 2 & \\
\hline & Very Low & $\begin{array}{l}\text { Settlement, } \\
\text { Swamp, Rice } \\
\text { field, }\end{array}$ & 1 & \\
\hline \multirow{4}{*}{ Litology } & High & $\begin{array}{l}\text { Alluvium } \\
\text { Deposits }\end{array}$ & 5 & \multirow{4}{*}{20} \\
\hline & Moderate & $\begin{array}{l}\text { Sandstone and } \\
\text { Limestone }\end{array}$ & 3 & \\
\hline & Low & $\begin{array}{l}\text { Volcanic } \\
\text { Breccia }\end{array}$ & 2 & \\
\hline & Very Low & Andesit & 1 & \\
\hline \multirow[t]{2}{*}{ Rainfall } & $\begin{array}{l}\text { Very high } \\
\text { High }\end{array}$ & $\begin{array}{l}>3000 \mathrm{~mm} / \mathrm{thn} \\
2000-3000\end{array}$ & $\begin{array}{l}5 \\
4\end{array}$ & \multirow[t]{2}{*}{20} \\
\hline & Very high & Regosol & 5 & \\
\hline \multirow[t]{2}{*}{ Soil type } & Moderate & Alluvial & 3 & \multirow[t]{2}{*}{15} \\
\hline & Very Low & Litosol & 1 & \\
\hline \multirow{5}{*}{ Slope } & Very high & $<8 \%$ & 5 & \multirow{5}{*}{10} \\
\hline & High & $8-15$ & 4 & \\
\hline & Moderate & $15-25$ & 3 & \\
\hline & Low & $25-40$ & 2 & \\
\hline & Very Low & $>40$ & 1 & \\
\hline \multirow{5}{*}{$\begin{array}{l}\text { River } \\
\text { density }\end{array}$} & Very high & $>2.7 \mathrm{~km} / \mathrm{km}^{2}$ & 5 & \multirow{5}{*}{5} \\
\hline & High & $2.12-2.7$ & 4 & \\
\hline & Moderate & $1.56-2.12$ & 3 & \\
\hline & Low & $0.95-1.56$ & 2 & \\
\hline & Very Low & $<0.95$ & 1 & \\
\hline \multirow{2}{*}{$\begin{array}{l}\text { Distance } \\
\text { from } \\
\text { Lineament }\end{array}$} & Very high & $<1.500$ meter & 5 & \multirow[b]{2}{*}{ p } \\
\hline & Very Low & $>1.500$ & 1 & \\
\hline
\end{tabular}

\subsection{Land Use Layer}

Land use maps in the study area were obtained from the Public Works and Spatial Planning Office of Purworejo regency. The use of space in Purworejo regency with total area of $107,980.67$ ha consists of 8 types of land use covering Rice field (34.669,05 ha), Swamp (354,6 ha), Shrubs (5,350,31 ha), Empty land (554.44 ha), Vacant land (5,621.38 ha), Gardens (39,826.62 ha), Forest (1,339.33 ha) and Settlements (19,062.06 ha). Rice fields, gardens and settlements dominate land use types in the study area. Types of land use with large amounts of vegetation indicate a high groundwater infiltration potential compared to the type of land use that lacks vegetation. Land use maps are presented in Figure 3.

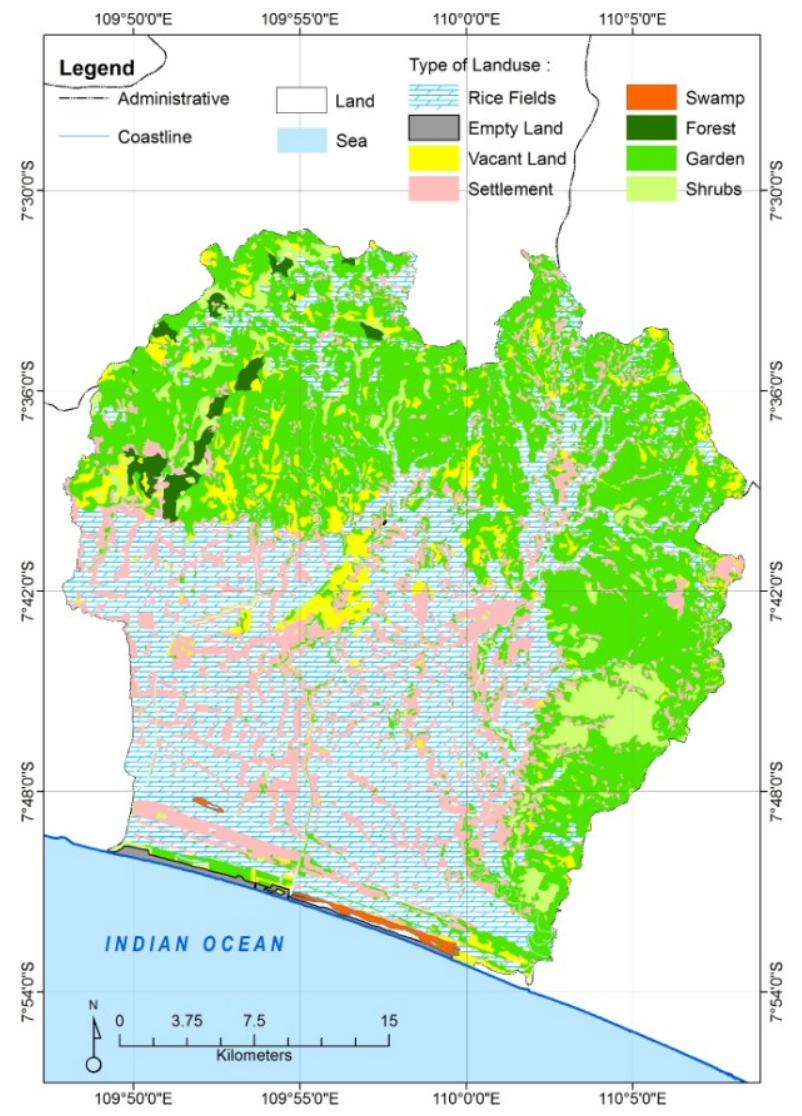

Fig. 3. Land use map of the study area.

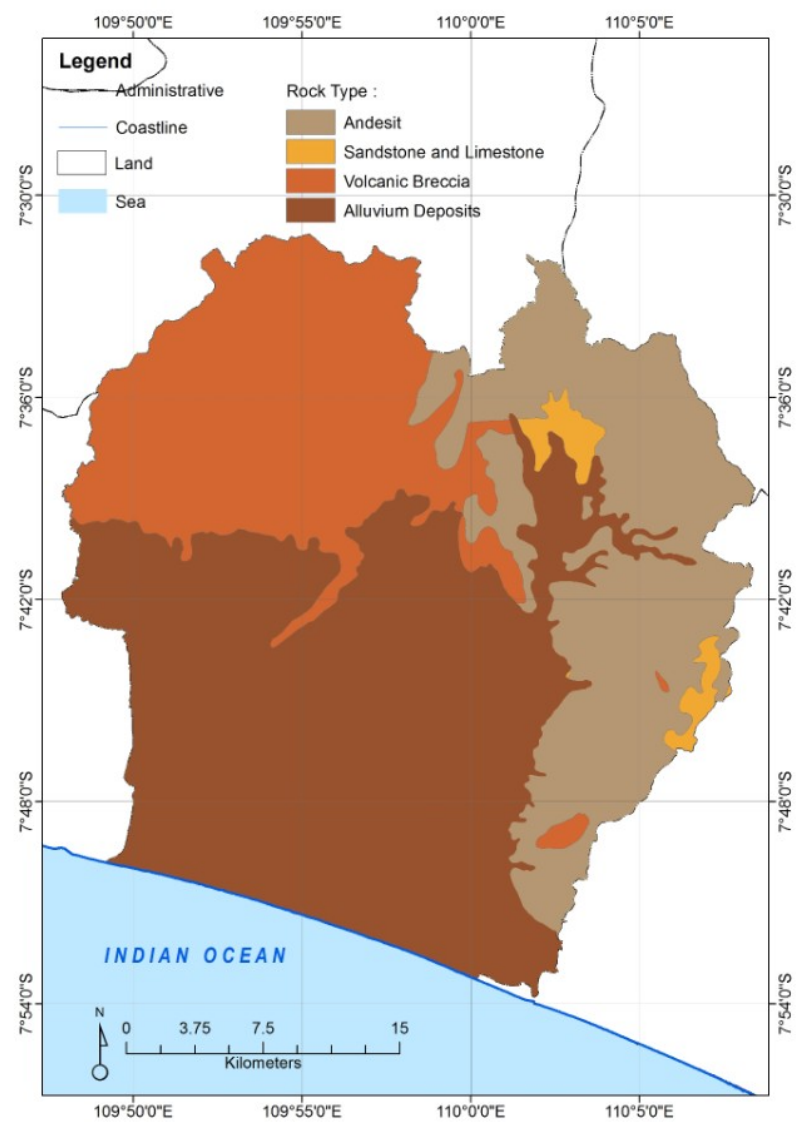

Fig. 4. Litology map of the study area. 


\subsection{Lithology layer}

Lithology map of Purworejo regency was prepared by scanning, geo-referencing and digitizing the 1: 25.000 geology map of central java. The study area consists of Andesite rock types $(26,580.56$ ha), Volcanic Breccia $(27,765.03 \mathrm{ha})$, Sandstone \& limestone (1,812.39 ha), and Alluvium deposits $(51,822.69 \mathrm{ha})$. The most potent Alluvium deposits types are potential for groundwater infiltration compared to other rock types. The study area lithology map is presented in Figure 4.

\subsection{Rainfall layer}

Rainfall in the study area is almost high seen from annual rainfall data. The rainfall map is obtained from average annual rainfall data from 2011 - 2016, then interpolated to get map of rainfall distribution. The level of rainfall in the study area is categorized Very high on the area of 60,531.13 ha and High area of 47,449.54 ha. Higher levels of rainfall are potentially infiltrates into the soil and stored as groundwater. The rainfall maps in the study area are presented in Figure 5.

\subsection{Soil type layer}

The soil type map in the study area is obtained from the spatial map of Purworejo regency, which consists of 3 types of land, Latosol $(68,580,56$ ha), Alluvial $(34,439$ ha), and Regosol (5,432 ha). Type of soil Regosol potentially infiltates groundwater better than alluvial and latosol soil types. The soil type charts in the study area are presented in Figure 6.

\subsection{Slope layer}

Slope is the rate of change of elevation, and is also a significant factor in identifying groundwater potential zones. Increased slope results in high runoff and erosion of surface soil [17]. The study area outline is lowland with a fairly sloping slope. Areas with a fairly steep slope exist only in the hills in the north and east. Study area with slope level of $<8 \%$ covering 55,305,69 ha, 8 $15 \%$ (19,579,02 ha), 15 - 25\% (17,415,96 ha), $25-40 \%$ $(11,252,22 \mathrm{ha})$, and $>40 \%(4,427,78 \mathrm{ha})$. The higher the slope of the land the run-off rate is greater, but the water absorption rate of the soil is smaller. In the area is actually suitable to be used as a conservation area, because the water level is increasingly large and the erosion rate is also getting bigger. The land slope map of the study area is presented in Figure 7.

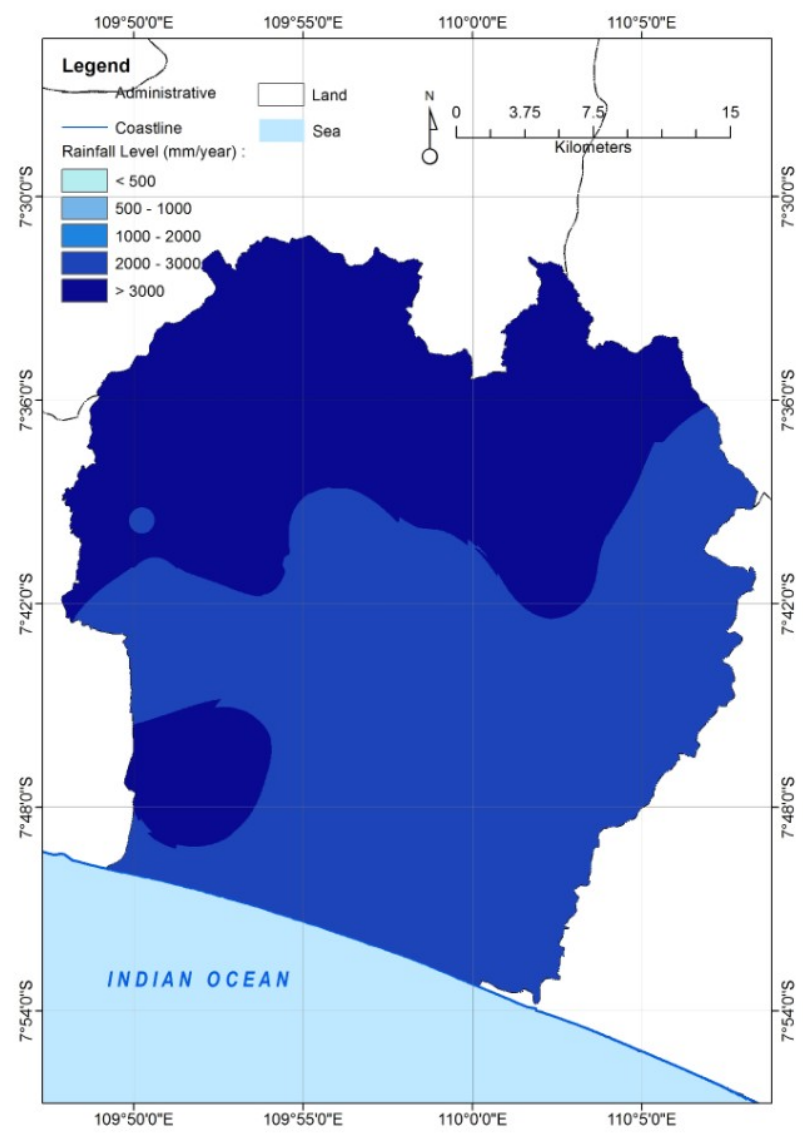

Fig. 5. Rainfall map of the study area.

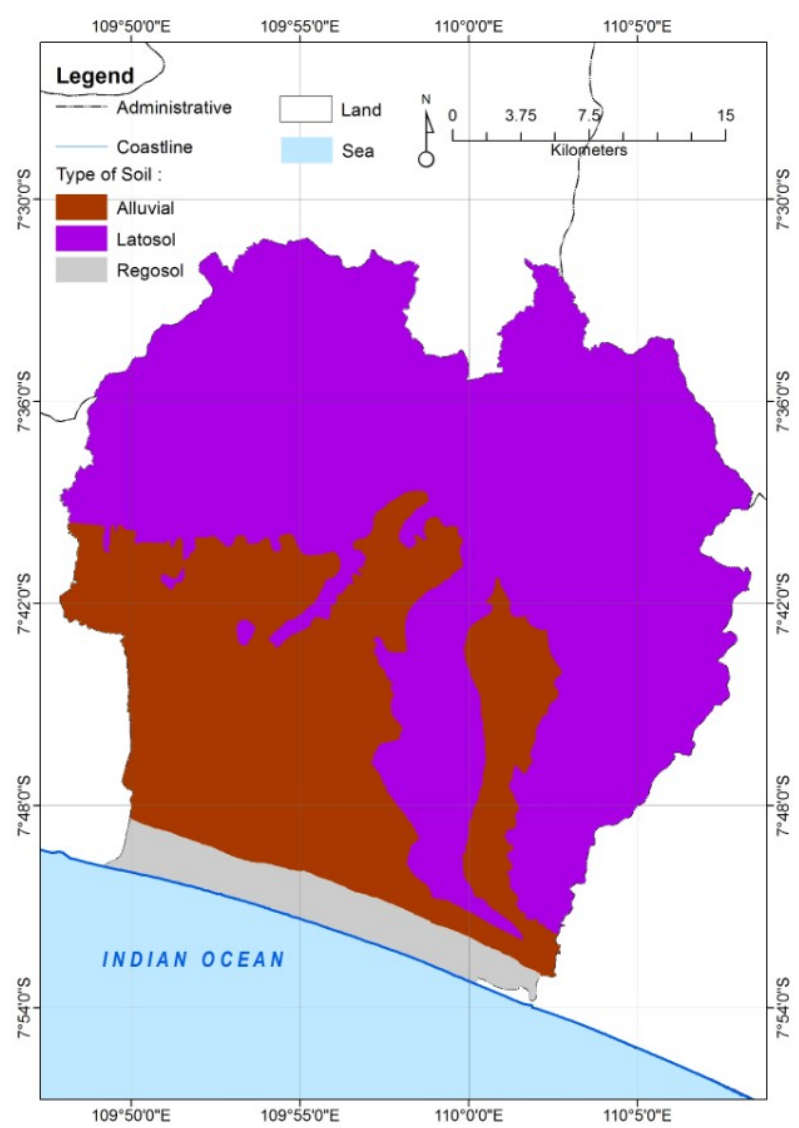

Fig. 6. Soil type map of the study area 


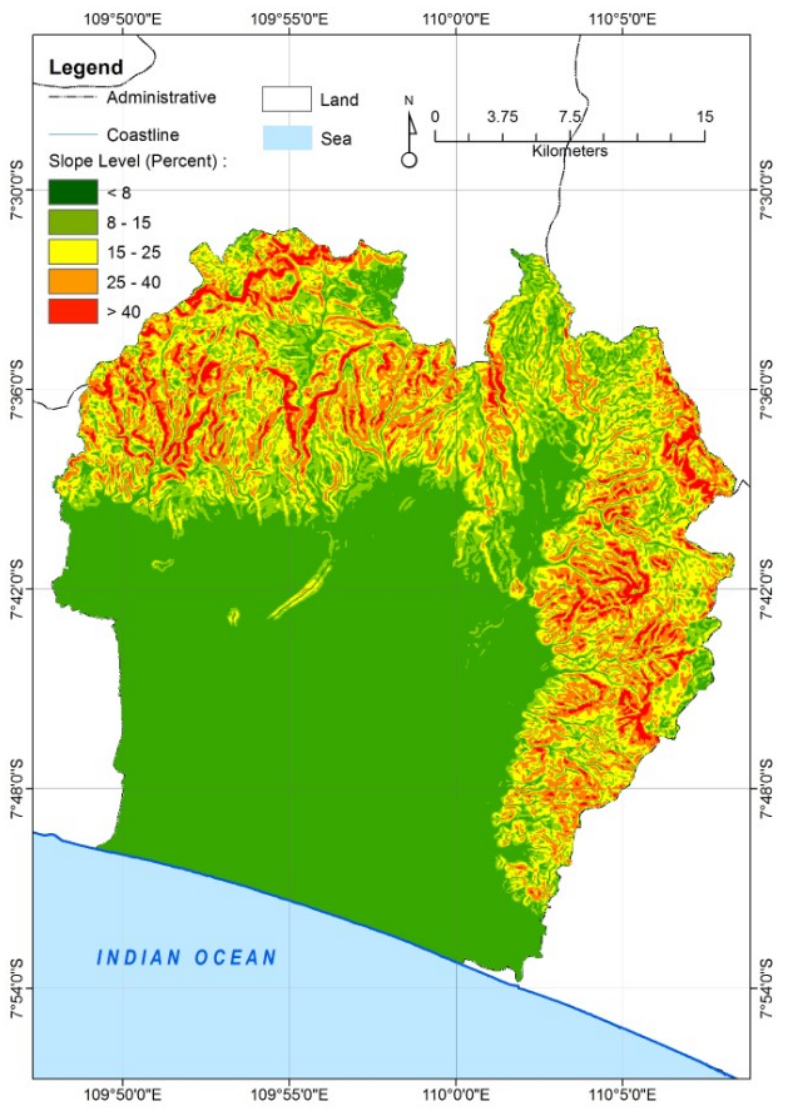

Fig. 7. Slope map of the study area

\subsection{River density layer}

River density levels indicate the potential for greater groundwater infiltration. In the study area, areas with large river densities are located in hilly areas. River density levels are divided into 5 categories, ie very high, high, medium, low, and very low. Areas with very high river density of 17,628 ha, High $(24,160,65$ ha), Medium (28,671, 27 ha), Low (27,968.28 ha), and Very Low $(9.662,29$ ha). A map of river density in the study area is presented in Figure 8.

\subsection{Distance from Lineament layer}

Lineament is structurally controlled linear or curvilinear features, which are identified from the satellite imagery by their relatively linear alignment. Lineaments represent the zones of faulting and fracturing resulting in secondary porosity and permeability. These are are hydro-geologically very important as they provide the pathways for groundwater movement [18]. In this study used lineament in the fault form as a potential zones for the infiltrates of groundwater which we known as non basin groundwater area. Map of this fault is obtained from the regional geological map of Central Java. The proximity level of a zone on the lineament indicates more potential for flowing into the lineament and then become groundwater. The distance from lineament map is shown in Figure 9.

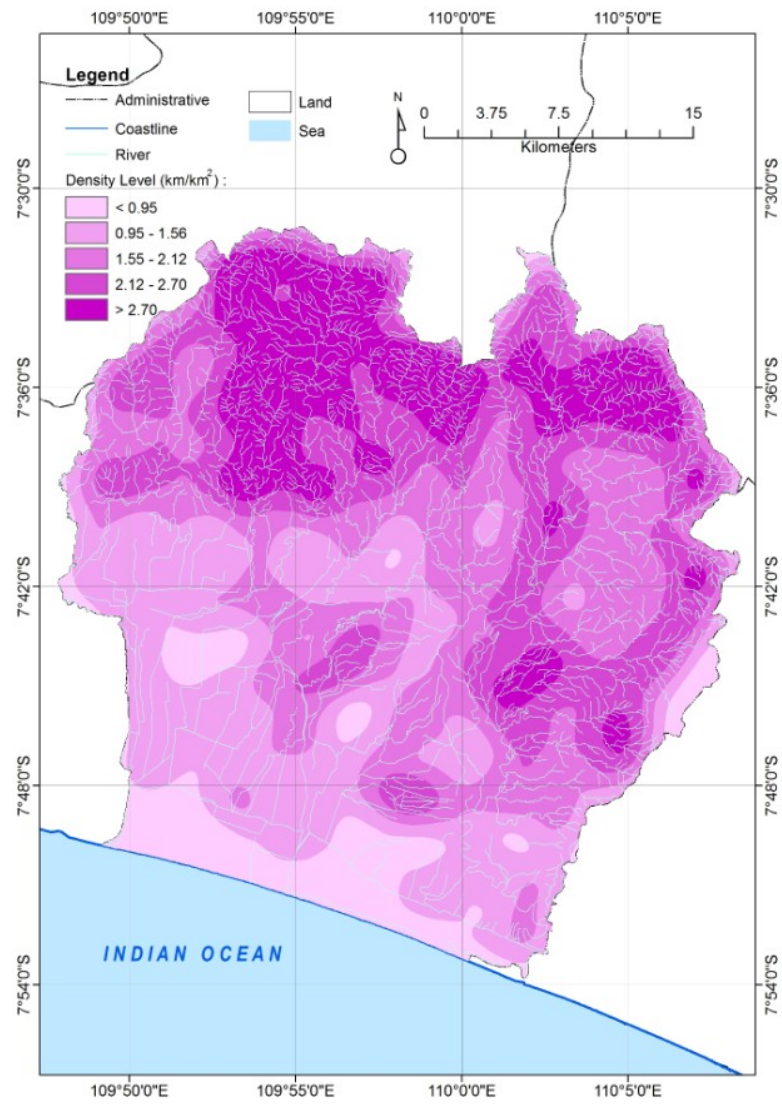

Fig.8. River density map of the study area

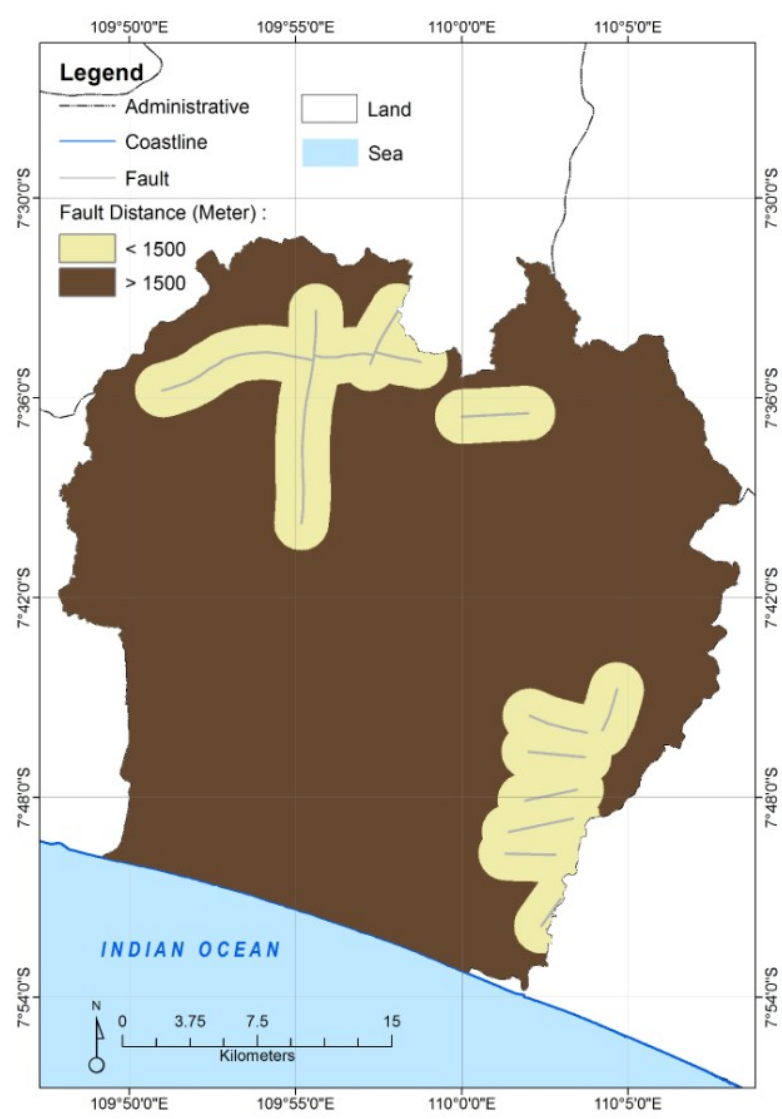

Fig. 9. Lineament map of the study area 


\section{Result}

The groundwater potential zones for the study area were generated through the integration of various thematic maps viz., land use, lithology, rainfall, soil type, slope, river density, and distance from lineament using GIS techniques. The demarcation of groundwater potential zones for the study area was made by grouping of the interpreted layers through weighted factor and finally assigned different potential zones. The groundwater recharge potential zone divided into five classes from very low into very high. According to the final map, the areas of very high occurs an area of 4.597 .56 ha, high (24.832,08 ha), moderate (38.675,79 ha), low (30.398,13 ha), and very low occurs in area of $9.477,09$ ha. Groundwater recharge potential zones map is shown in figure 10 .

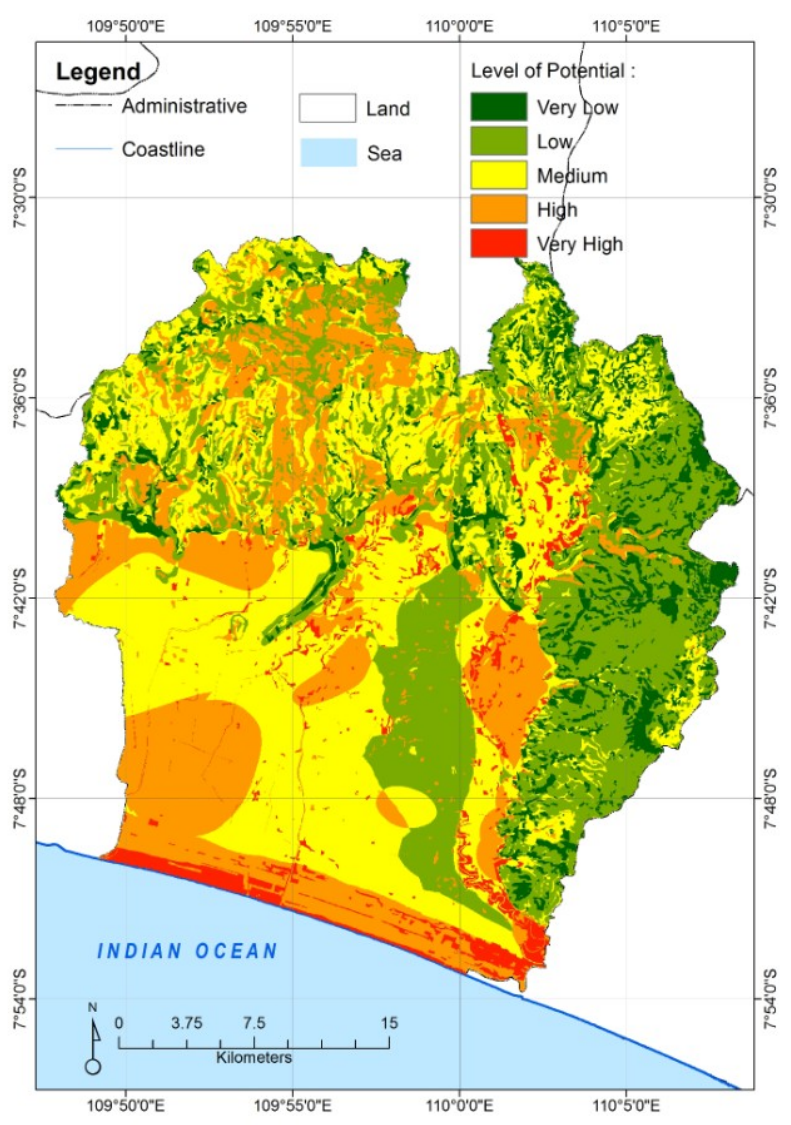

Fig. 10. Groundwater recharge potential zone map of the study area

\section{Conclusions}

Mapping groundwater recharge potential zones using Geographic Information System is one technique that is very effective and efficient. From the results of this study to describe the region with the potential to infiltrates rainwater into groundwater as consideration for policy makers to preserve and conserve groundwater. The results of this study can also be used as a reference in the revised spatial planning Purworejo.

\section{Reference}

1. Kodoatie JR. Tata Ruang Air Tanah.; (2012).

2. Nugroho SP. Evaluasi Keseimbangan Air di Provinsi Jawa Tengah, 3(2):175-182, (2007)

3. Wibowo M. Model Penentuan Kawasan Resapan Air untuk Perencanaan Tata Ruang Berwawasan Lingkungan, 1(1): 1-7, (2006)

4. Yuliana. (2016). Kesiapsiagaan Masyarakat dalam Menghadapi Bencana Banjir di Desa Bendungan, Kecamatan Grabag, Kabupaten Purworejo 4. Adi, H. P. (2011). Kondisi dan Konsep Penanggulangan Bencana Kekeringan Di Jawa Tengah. Seminar Nasional Mitigasi Dan Ketahanan Bencana, 1-10. http://doi.org/978-602-8420-85-3.

6. A. Ekadinata, S. Dewi, D. Hadi, D. Nugroho, and F. Johana, World Agroforestry Centre, Bogor, Indonesia, (2008)

7. M. A. Manap, H. Nampak, B. Pradhan, S. Lee, W. N. A. Sulaiman, and M. F. Ramli. Arabian Journal of Geosciences, 7(2), 711-724, (2014) https://doi.org/10.1007/s12517-012-0795-z

8. A. Madani, B. Niyazi, Environ Earth Sci.74(6):51295142, (2015) doi:10.1007/s12665-015-4524-2.

9. SF. Elbeih, Ain Shams Eng J, 6(1):1-15, (2015) doi:10.1016/j.asej.2014.08.008.

10. M. Nagarajan, S. Singh, J Indian Soc Remote Sens, 37(1):69-77, (2009) doi:10.1007/s12524-009-0012-z.

11. D. Oikonomidis, S. Dimogianni, N. Kazakis, K. Voudouris, J Hydrol. 525:197-208, (2015) doi:10.1016/j.jhydrol.2015.03.056.

12. IP. Senanayake, Dissanayake DMDOK, BB. Mayadunna, WL. Weerasekera. Geosci Front.7(1):115-124, (2016).

13. Badan Pusat Statistik. Kabupaten Purworejo dalam angka. [internet].(2016). Available from: https://www.purworejokab.bps.go.id/index.php/publik asi/index?Publikasi\%5BtahunJudul\%5D=\&Publikasi $\% 5$ BkataKunci $\% 5 \mathrm{D}=$ purworejo+dalam+angka \&yt 0

14. Presiden P. KEPUTUSAN PRESIDEN REPUBLIK INDONESIA NOMOR 26 TAHUN 2011 TENTANG PENETAPAN CEKUNGAN AIR TANAH. 1999:116.

http://www.komnasham.go.id/sites/default/files/doku men/UU NO 39 TAHUN 1999 HAM_0.pdf.

15. H. Yeh, Y. Cheng, H. Lin, C. Lee. Sustain Environ Res, 26(1):33-43, (2016).

16. T. N. Adji, and S. P. Sejati, Identification of groundwater potential zones within an area with various geomorphological units by using several field parameters and a GIS approach in Kulon Progo Regency , Java , Indonesia, 161-172. https://doi.org/10.1007/s12517-012-0779-z16.

17. SA. Ahmed, Egypt J Remote Sens Sp Sci, 19(2):223234, (2016) doi:10.1016/j.ejrs.2016.06.002.

18. NS. Magesh, N. Chandrasekar, JP. Soundranayagam, Geosci Front, 3(2):189-196, doi:10.1016/j.gsf.2011.10.007.

19. A. A. Sigit, Pemanfaatan Teknologi Penginderaan Jauh dan Sistem Informasi Geografis untuk Pendugaan Potensi Peresapan Air DAS Wedi Kabupaten Klaten-Boyolali, 25(1), (2011).

20. N. Adibah, S. Kahar, B. Sasmito, Aplikasi Penginderaan Jauh dan Sistem Informasi Geografis untuk Analisis Daerah Resapan Air (Studi Kasus: 
Kota Pekalongan).2(April):141-153, (2013)

21. Bappenas, Studi Prakarsa Strategis SDA untuk Mengatasi Banjir dan Kekeringan di Pulau Jawa. Tidak Diterbitkan. Jakarta, (2005) 